\title{
Optimization of Literated Culture Through the Utilization of the Reading Area at SDN 3 Mojorebo, Wirosari District, Grobogan Regency
}

\section{Merliana Dyah Nurmalasari ${ }^{*}$, Husni Wakhyudin ${ }^{2}$, Intan Rahmawati ${ }^{3}$}

1,23 PGSD FIP Universitas PGRI Semarang

\section{A R T I C L E I N F 0}

Article history:

Received 15 February

2019

Received in revised

form

29 March 2019

Accepted 18 April 2019

Available online 25 May 2019

Keywords:

literacy culture, benefit of reading corner area

\section{A B S T R A C T}

This study aims to describe 1) the efforts of the school to introduce a culture of reading 2) optimize the reading culture 3) obstacles in optimizing the use of the reading corner area 4) solutions to obstacles in optimizing the reading culture. The type of research used is qualitative research. The informants in this study were principals, teachers and children who had problems learning to read. Research results show that: 1) Efforts from the school to foster students' reading culture are conveyed by the principal by inviting publishers to provide choices of books to be given to students. 2) the benefits of reading corners provide a new atmosphere in the classroom, also when there is free time can be used to read. In addition, making students enjoy reading by being guided by the teacher. 3) Obstacles in optimizing literacy culture, namely the difficulty of fostering a reading culture early on. 4) Solutions in optimizing the culture of literacy, among others, the teacher provides reading books that are appropriate to the needs of students and try to add a collection of reading so that students do not get tired of reading in the reading corner. 


\section{Introduction}

Education is a very important thing in life. Education is essentially a transfer of knowledge and carried out by individuals to other individuals, to change a person's behavior or individual's attitude from the unknowing to the knowing.

Education is a conscious and planned effort to create an atmosphere of learning and learning process so that students actively develop their potential to have religious spiritual intelligence, selfcontrol, personality, intelligence, noble character, and the skills needed by themselves in society, nation and country (Kemendikbud, 2003).

Education defined as the process of changing attitudes, behavior and knowledge through the learning process. Learning will be achieved if students have a skill. One of the skills students must possess is reading skill.

Reading is very important. Because reading is a window to the world, it means that reading all the information in the corners of the world can be known by someone easily. Students who read frequently will have more extensive insight than students who lack of reading. Therefore, the ability to read is a provision and key to the success of a student in education process at school.

Efforts are taken to realize the habit of reading to students through the School Literacy Movement. In this activity the government involves all school members (teachers, students, parents / guardians of students) and the community, as part of the education ecosystem. The Ministry of Education and Culture (Kemendikbud) continues to improve reading culture for Indonesian people, especially for students. One of them is through the Minister of Education and Culture (Permendikbud) Regulation No. 23 Tahun 2015 that concern in Development of character to students by developing School Literacy Movement. According to Abidin (2017: 279) the School Literacy Movement is a social movement with collaborative support from various elements. School is one of the formal institutions in developing students' talent, creativity, and intellectual needs to develop practices and skills in expressing and understanding ideas and information using conventional text forms, innovative text forms, symbols and multimedia (Abidin, 2017) .

Learning in schools should be directed towards multilateral learning which includes activities: (a) literacy as a series of reading, writing, speaking, arithmetic and numeracy skills, and skills in accessing and using information; (b) literacy as a social practice whose application is influenced by context; (c) literacy as a learning process with reading and writing activities as a medium for pondering, investigating, asking and criticizing knowledge and ideas learned; (d) literacy as a text that varies according to subject, genre, and level of language complexity (Ministry of Education and Culture: 2018)

Based on the results of interviews about literacy culture at SDN 3 Mojorebo, it has been implementing literacy culture since 2017. The implementation of literacy culture at SDN 3 Mojorebo can be seen in the following activities; (1) socialization held by the Grobogan Regent in 2017 about the implementation of a culture of literacy that must be held in schools, (2) the availability of various student reading books from fiction and non-fiction books from the Grobogan government, (3) 15-minute reading activities every day before hours the lesson begins. The School Literacy Movement Program, which is implemented at SDN 3 Mojorebo, is implemented as a good practice in optimizing literacy culture through the reading corner area for students.

Based on the background explanation above, the researcher was interested in making the optimization of literacy culture a research topic because literacy can encourage students to enjoy reading through the reading corner area.

School involvement is very important in implementing a program as has been done before in developing a culture of reading in schools. Reading culture in schools is very necessary, in addition to improving the quality of learning, it can also develop students' abilities, so that learning becomes more meaningful, quality and enjoyable. To realize this, the school needs to facilitate one of them by making reading corners in class.

Literacy that utilizes the reading corner area contained in the classroom has several functions. Fijayanti (2014) argues that the reading corner has several functions including (a) facilitating the classroom by utilizing the classroom corner as a place to provide reading material while making it part of the school's needs in building literacy activities so as to create a conducive atmosphere when there are no other activities or free time; (b) make students confident because of the reading angle, the majority of students can retell the stories they read (story telling). Story telling requires students to be willing to go forward to retell the story they are reading, thereby making students confident and improve their ability to communicate.

At the elementary school, it provides a reading corner for students' reading activities in class, but cannot be optimized by students. There are students who lack of confidence to join their friends to read because they are not fluent in reading, and those who cannot participate in reading because of the narrow 
reading corner. Even though there is a reading corner expected to foster a reading culture. The role of the school, such as the principal and teacher, is needed to guide students in reading corner to know and understand the importance of reading. Based on the statement above, the researcher is interested in optimization of literacy culture with the title "Optimization of Literacy Culture through Utilization of Reading Corner Areas".

\section{Methods}

This type of research is descriptive research. In descriptive research the data collected in the form of words or pictures so that it does not emphasize numbers.

The type of research that researchers use is qualitative research. This study uses a qualitative approach that refers to the theory of Moloeng. Researchers saw how the implementation of literacy culture in SDN 03 Mojorebo. Qualitative research is research that intends to understand phenomena about what is experienced by research subjects such as behavior, perception, motivation, action, etc., holistically, and by describe in the form of words and language, in a special natural context by utilizing various natural methods.

Through this qualitative research, researchers examine the problems or phenomena that during literacy cultural activities. Data collected in this study came from observations in literacy cultural activities, interviews with teachers, documentation and questionnaires for students. By carrying out this research it is hoped that information about optimizing literacy culture can be realized by students in their daily lives by utilizing the reading corner area..

\section{Result And Discussion}

Observing and analyzing the results of observations, questionnaires, and in-depth interviews with resource persons equipped with documentation studies, as well as in-depth observations, a general description of the findings and research findings related to the optimization of literacy culture through the use of reading corner areas in SDN 3 Mojorebo, Wirosari sub-district, Grobogan Regency, covers the implementation of literacy culture, the components that play a role in the implementation of literacy culture, infrastructure that supports literacy culture and efforts taken to increase student reading interest.

The results showed that the implementation of literacy culture in SDN 3 Mojorebo, Wirosari Grobogan, has been running since 2017, in accordance with Minister of Education and Culture Regulation (Permendikbud) No. 21 Tahun 2015 concern in Development of Character Building for students by developing the School Literacy Movement. Literacy cultural activities take 15 minutes before the lesson.

The components that play a role in the implementation of literacy culture in SDN 3 Mojorebo Wirosari Grobogan are the principal, teachers, school staff, and students. In this activity principals and class teachers play an important role in the implementation of literacy culture. In addition, motivators and facilitators, school principals and class teachers are also involved in literacy cultural activities in schools. Where the school principal regulates the course of literacy culture and provides examples and directions so that literacy culture goes well. As well as the teacher who helped their students in the implementation of literacy culture and help students to choose the right reading books for students.

To help teachers in the implementation of literacy culture, a lot of facilities and infrastructure must be met to optimize literacy. According to Abidin Yunus (2017), school facilities and infrastructure are the fourth basic capital for the creation of literacy schools. These facilities and infrastructure pertain to teaching materials (text), libraries, reading corners, literacy centers, facilities and infrastructure related to school literacy culture. With regard to reading corners, reading corners are reading rooms located in the corner of the classroom. With a corner to read in class, students do not need to go to the school library that is located far from the class. The purpose and benefits of holding a reading corner in the classroom is to instill students' interest in reading books, not only textbooks or lessons, but story books that are popular with students and direct students become fonder of books. The advantages of holding a reading corner are that it makes it easier for teachers to invite students to read books during recess, get students closer to books, and attract students to enjoy reading books in class. In addition, the lack of a reading corner is a place that is less extensive, so students are less free to read.

In implementing literacy culture in SDN 3 Mojorebo, Wirosari Grobogan, teachers have ways or efforts to increase students' interest in reading, preparing interesting reading books for students to read and invite students to read collections of books at home and in the reading corner of the class, and invites students to exchange books with their friends. The teacher also gives small prizes such as ballpoints, pencils, to students who are diligently participating in literacy cultural activities in class, so students who are less diligent can be motivated to be more diligent in following literacy cultural activities 


\section{Conclussion}

Based on the description of the results of research and discussion that researchers have done related to the optimization of literacy culture in SDN 3 Mojorebo, Wirosari Grobogan and has been described previously, the following conclusions can be drawn:

1. Implementation of literacy culture

Literacy culture implementation in SDN 3 Mojorebo Wirosari, running since 2017, this activity is carried out 15 minutes before the lesson. Components that play a role in literacy culture implementation in SDN 3 Mojorebo Wirosari are the principal, teachers, school staff, and students.

2. Factors that support the implementation of literacy culture

The implementation of literacy culture activities also influenced by several factors, the components that play a role in the implementation of literacy culture carrying out their respective duties and roles, and the availability of adequate infrastructure, where the availability of school libraries or special spaces and reading class are used to save non-lesson books. In addition there is rich text material in each class and reading campaign posters in class.

3. Factors that inhibiting the implementation of literacy culture

In the development of literacy cultural activities in SDN 3 Mojorebo, there is no public involvement of alumni and other communities, schools only involve parents. And there are obstacles in the form of less extensive reading angles and the limited number of books in the reading corner.

Suggestion

1. Researchers hope that this research can be a reference related to the optimization of literacy culture.

2. For schools, schools should add to the collection of reading books in the reading corner.

3. For students, students should read books more often, exchange stories with friends, so students get broad knowledge..

\section{Reference}

Abidin, Yunus, Tita Mulyati, dan Hana Yunansah. 2017. Pembelajaran Literasi :Strategi Meningkatkan Kemampuan Literasi Matematika, Sains, Membaca, dan Menulis. Bumi Aksara. Jakarta

Fijayanti,Ira Uffa Dwi Ratih. 2014. Program Membaca Lima Belas Menit (Sustained Silent Reading) Pada Siswa dan Siswi Sekolah Dasar Negeri di Kota Surabaya 1 Program Membaca Lima Belas Menit (Sustained Silent Reading) Pada Siswa dan Siswi Sekolah Dasar Negeri di Kota Surabaya. Malang : FISIP UNAIR.

Kemendikbud.Peraturan Menteri Pendidikan dan Kebudayaan Nomor 21 Tahun 2015.Tentang Penumbuhan Budi Pekerti.

Moleong, Lexy J. 2017. Metode Penelitian Kualitatif. Bandung: PT Remaja Rosdakkarya. Edisi Revisi.

Nugroho,Alfian Handina, Ratna Puspitasari, dan Euis Puspitasari, 2016, Implementasi Gemar Membaca Melalui Program Pojok Baca Dalam Mata Pelajaran IPS Pada Siswa Kelas VIII Di SMPN 2 Sumber, Jurnal Edueksos,Vol. V, No. 2

Permendikbud. 2015. Penumbuhan Budi Pekerti. Jakarta 